\title{
Penerapan Model Salah Berantai Tema Tujuh (Indahnya Keragaman Negeriku) Upaya Meningkatkan Motivasi dan hasil belajar Peserta Didik Kelas IV Semester Dua Tahun Pelajaran 2018/2019 di SD Negeri 30 Mataram
}

\author{
Sudiati \\ Guru Kelas IV SD Negeri 30 Mataram
}

\begin{abstract}
Abstrak. Penelitian ini bertujuan untuk mengetahui efektifitas penerapan model Pembelajaran "Benar Salah Berantai" dalam upaya meningkatkan motivasi dan hasil belajar peserta didik Kelas IV SD Negeri 30 Mataram. Manfaat penelitian ini adalah mendorong peserta didik untuk mengembangkan ketrampilan belajar dalam kelompok (kognitif) dan bersosiolisasi dengan teman sebagai dalam proses pembelajaran di kelas senyatanya. Dan bagi guru meningkatkan pengembangan pendekatan dan model pembelajaran dengan penerapan saintifik dan strategi discovery learning dalam pembelajaran kerja kelompok (kooperatif) dengan metode diskusi. Penelitian ini dilaksanakan dua siklus, masing-masing siklus kegiatannya adalah perencanaan, pelaksanaan, observasi dan refleksi. Hasil akhir tindakan pada siklus II menunjukkan bahwa hasil observasi guru sebesar 4,71, hasil observasi Peserta didik mencapai skor rata-rata $(4,44)$. Sedangkan dampak dari peningkatan motivasi belajar adalah meningkatnya perolehan hasil belajar siswa mencapai nilai rata-rata $(88,44)$, artinya indicator keberhasilan $(\geq 4,0)$ dan hasil belajar $(\geq$ $75,00)$ telah terlampaui. Karena indicator keberhasilan telah terbukti penelitian dinyatakan berhasil dan dihentikan pada siklus II.
\end{abstract}

Kata Kunci : Motivasi dan hasil Belajar-Model Pembelajaran Benar Salah Berantai.

\section{PENDAHULUAN}

\section{Latar Belakang}

Proses belajar mengajar merupakan aktivitas yang mengandung serangkaian kegiatan interaksi timbal balik antara guru dan peserta didik dengan cara saling kolaborasi dalam memberikan dan menerima materi pelajaran di kelas senyatanya. Hubungan timbal balik dimaksud berlangsung dalam situasi edukatif formal untuk mencapai tujuan pembelajaran yang telah direncanakan. Motivasi peserta didik dalam proses pembelajaran sangat diprioritaskan dalam upaya mencapai hasil belajar yang tinggi dan mampu menciptakan kondisi kegiatan pembelajaran yang aktif, inovatif, kreatif, efektif, dan menyenangkan (PAIKEM). Proses pembelajaran yang demikian akan mampu menumbuhkembangkan karakter peserta didik sesuai dengan kurikulum tahun 2013 (K.13), yang diharapkan mencetak generasi milenial menuju abad 21.

Prose pembelajaran di SD Negeri 30 Mataram selama ini sudah ada upaya konkrit dari guru kelas untuk melaksanakan pembelajaran yang aktif, inovatif, kreatif, efektif, dan menyenangkan (PAIKEM), akan tetapi masih belum optimal. Situasi peserta didik di kelas masih cenderung kurang kondusif. Hal ini dapat dipaparkan bahwa selama proses pembelajaran sikap peserta didik terkesan acuh tak acuh, masih banyak yang main-main, berpindah-pindah posisi duduk, keluar masuk kelas tanpa ijin, dan bahkan ada dijumpai peserta didik yang tidak pernah mau mencatat dan tidak mau mengerjakan tugass dari guru. Yang lebih parah lagi ada peserta didik yang terlelap tidur, main HP, dan perilaku lain yang berdampak kurang kondusifnya dalam proses pembelajaran di kelas senyatanya.

Adapun faktor penyebab kurang kondusifnya dalam proses pembelajaran adalah: 1) model pembelajaran yang diterapkan oleh guru cenderung ke guru sentris, dimana guru menjelaskan materi dengan berapi-api, peserta didik tidak boleh bertanya, duduk manis mencatat apa yang ditugaskan oleh guru, 2) peserta didik kurang termotivasi apalagi berpikir kritis dan sistematis, kecendrungan melakukan kegiatan sendiri tanpa memperdulikan materi 
pelajaran, 3) motivasi belajar peserta didik sangat rendah, hal ini dapat dilihat ketika guru menjelaskan materi pelajaran, guru bertanya "adakah yang bertanya, sudah jelas", semua peserta didik membisu/semua diam tidak ada yang berkomentar.

Sebenarnya banyak solusi yang bisa dilakukan oleh guru dalam upaya meningkatkan motivasi dan hasil belajar peserta didik, tetapi berdasarkan pengalaman guru selaku peneliti ada satu model yang dianggap jitu dan tetap untuk meningkatkan motivasi dan hasil belajar. Model pembelajaran dimaksud adalah "Model Benar Salah Berantai". Alasan memilih model pembelajaran ini karena memiliki beberapa keunggulan bila dibandingkan dengan model pembelajaran yang lain. Adapun keunggulan dimaksud berdasarkan pengetahuan dan pengalaman peneliti adalah: 1) mendorong peserta didik untuk bekerjasama dalam kelompok, 2) dengan model pembelajaran "Benar Salah Berantai" ini peserta didik dapat belajar dengan cepat untuk materi yang banyak, 3) materi-materi yang bahannya dimiliki peserta didik dengan sangat baik diajarkan dengan menggunakan model pembelajaran ini, dan 4) motivasi dan hasil belajar peserta didik dapat ditingkatkan.

Untuk membuktikan bahwa model pembelajaran "Benar Salah Berantai" ini memiliki beberapa keunggulan, maka peneliti mengadakan Penelitian Tindakan Kelas (PTK) dengan judul: "Penerapan Model Salah Berantai Tema Tujuh (Indahnya Keragaman Negeriku) Upaya Meningkatkan Motivasi dan hasil belajar Peserta Didik Kelas IV Semester Dua Tahun Pelajaran 2018/2019 di SD Negeri 30 Mataram".

\section{Rumusan Masalah}

"Bagaimana penerapan model Benar Salah Berantai dalam proses pembelajaran upaya meningkatkan motivasi dan hasil belajar peserta didik kelas IV semester dua tahun pelajaran 2018/2019 di SSD Negeri 30 Mataram?"

\section{Tujuan Penelitian}

"untuk mengetahui efektivitas pelaksanaan model pembelajaran "Benar Salah Berantai” pada tema tujuh (Indahnya keberagaman Negeriku) upaya meningkatkan motivasi dan hasil belajar peserta didik kelas IV semester dua tahun pelajaran 2018/2019 di SD Negeri 30 Mataram".

\section{Manfaat Penelitian}

- Bagi Peserta Didik : 1) Mendorong peserta didik untuk mengembangkan ketrampilan belajar dalam kelompok (kognitif) dan bersosiolisasi dengan teman sebagai dalam proses pembelajaran di kelas senyatanya, 2) Motivasi belajar bagi peserta didik dalam upaya pemahaman secara mandiri (eksplorasi) terhadap mata pelajaran yang diajarkan sehingga hasil belajar dapat ditingkatkan.

- Bagi Guru : 1) Meningkatkan pengembangan pendekatan dan model pembelajaran "Benar Salah Berantai" dalam pembelajaran dikelas senyatanya, 2) Menumbuhkan aspirasi secara ilmiah dalam menjalankan profesi keguruan terutama dalam pengembangan keprofesian berkelanjutan (PKB) bagi guru kelas.

\section{KAJIAN PUSTAKA \\ Kerangka Teori \\ Motivasi}

Motivasi berasal dari bahasa latin Movere yang berarti dorongan atau daya penggerak. Motivasi adalah daya penggerak yang menciptakan rangsangan belajar seseorang, agar mereka aktif belajar secara efektif dan terintegrasi dengan segala usaha mencapai hasil belajar yang memuaskan. Menurut Mc. Donald C (dalam Nurhayati;2006) bahwa motivation is a energy change within the person characterizet by affective arraousal and anticipatory goal reactions. Motivasi adalah suatu perubahan energy di dalam pribadi seseorang yang ditandai dengan timbulnya efektif (perasaan) dan reaksi untuk mencapai tujuan. Peserta didik yang memiliki motivasi yang kuat akan mempunyai banyak energy untuk melakukan kegiatan belajar. Hasil belajar akan optimal kalau ada motivasi. Semakin tepat motivasi yang diberikan maka akan semakin belajar pula pelajaran itu.

Berdasarkan konsep motivasi dari beberapa teori di atas, maka motivasi belajar dirumuskan sebagai kecenderungan peserta 
didik mengembangkan diri, dengan melakukan kegiatan belajar yang didukung oleh hasrat yang kuat untuk mencapai prestasi sebaik mungkin. Dan harus memperhatikan indicator motivasi sebagai berikut: 1) harapan sukses, 2) kerja keras, 3) tanggung jawab dan disiplin, 4) kemandirian dalam bertindak, 5) berani mengambil resiko, dan, 6) berusaha mencari cara-cara baru dalam memecahkan masalah sehingga akan meningkatkan keefektifitasan kondisi belajar.

Dalam kegiatan belajar mengajar, apabila ada seorang peserta didik, misalnya tidak berbuat sesuatu yang seharusnya dikerjakan, maka perlu diselidiki sebab-sebabnya. Sebabsebab itu biasanya bermacam-macam, mungkin iya tidak senang, mungkin sakit, lapar, ada problem pribadi dan lain-lain. Hal ini berarti pada diri anak tidak terjadi perubahan energy, tidak terangsang efeksinya untuk melakukan sesuatu, karena tidak memiliki tujuan atau kebutuhan belajar. Keadaan semacam ini perlu dilakukan daya upaya yang dapat menemukan sebab musababnya dan kemudian mendorong seorang peserta didik itu mau melakukan pekerjaan yang seharusnya dilakukan, yakni belajar. Dengan kata lain peserta didik itu perlu diberikan rangsangan agar tumbuh motivasi pada dirinya. Atau singkatnya perlu diberikan motivasi. (Sudirman:1996:74-75)

\section{Hasil belajar}

Masalah evaluasi hasil belajar meliputi alat ukur yang digunakan, cara menggunakan, cara penilaian dan evaluasinya (Harus Rasid dan Mansur, 2008:9). Evaluasi hasil belajar yang berhubungan dengan tugas guru rutin dilakukan evaluasi hasil, yang juga dijadikan umpan balik, evaluasi hasil bertujuan menilai apakah hasil belajar dicapai sesuai dengan tujuan (Lukmanul Hakim, 2008:165). Pakar pendidikan lain mendefinisikan bahwa yang dimaksud hasil belajar adalah perubahan perilaku secara keseluruhan bukan salah satu aspek potensi kemanusiaan saja (Supriyono, 2009:19). Berbeda dengan pendapatnya Bloom (Dalam Sumiati danAska, 2008). Hasil belajar mencakup kemampuan kognitif, afektif, dan psikomotorik. Jadi pendapat ini mengisyaratkan bahwa haasil belajar peserta didik harus diukur dengan tes tertulis, tes sikap, dan kemampuan skil secara nyata selama proses pembelajaran di kelas senyatanya. Dalam penelitian ini yang dimaksud dengan hasil belajar adalah tes ulangan harian yang dilaksanakan secara tertulis pada akhir pembelajaran dan nilai hasil diskusi kelompok yang dinilai secara perorangan.

\section{Model Pembelajaran "Benar Salah Berantai"}

Strategi ini merupakan pengembangan dari strategi Benar atau Salah yang telah dijelaskan sebelumnya. Strategi ini mendorong kerjasama kelompok dalam belajar. Dengan stratgei ini peserta didik dapat belajar dengan cepat untuk materi yang banyak. Materi-materi yang bahan caannya dimiliki oleh peserta didik akan sangat baik diajarkan dengan menggunakan strategi.

\section{Langkah-langkah}

1. Tentukan topic yang akan dipelajari, dan tentukan juga bahan bacaannya.

2. Buatlah beberapa pertanyaan tentang teks bacaan yang mengandung benar atau salah

3. Pernyataan-pernyataan tadi dikelompokkan menjadi beberap kelompok dan masing-masing kelompok ditulis dalam selembar kertas. Setiap diberi tanda A, B, C dan seterusnya. Dengan demikian jika kertas A berisi tiga pernyataan maka kertas $\mathrm{B}, \mathrm{C}$, dan seterunya akan mempunyai tiga pernyataan pula.

4. Bagilah peserta didik menjadi beberapa kelompok sesuai dengan jumlah kertas yang dibuat. Usahakan masing-masing kelompok terdiri dari 3-4 orang. Jangan terlalu banyak agar setiap orang dapat member kontribusi secara aktif.

5. Setiap kelompok diberi kertas yang sudah berisi pernyataan-pernyataan. Dengan ini akan didapatkan kelompok 1 memegang kertas A, kelompok 2 memegang kertas $\mathrm{B}$, kelompok 3 memegang kertass $\mathrm{C}$, dan seterusnya.

6. Tugas setiap kelompok adalah menuliskan pernyataan-pernyataan yang mereka miliki kemudian menentukan apakah pernyataan-pernyataan tersebut 
benar atau salah. Catatan: kertas tidak boleh ditulisi atau diberi tanda apa saja.

7. Setelah semua kelompok selesai melakukan tugas kertas diputar untuk diberikan kepada kelompok disampingnya. Dengan ini kelompok 2 akan mendapatkan kertas baru, kertas A kelompok 3 menerima kertas B kelompok 4 menerima kertas $C$, dan seterusnya. Sementara kelompok satu akan menerima kertas dari kelompok terakhir

8. Setelah masing-masing kelompok menerima kertas yang baru tugas seperti pada langkah no: 6 diulangi

9. Setelah selesai, diulangi langkah no; 7 dan langkah no; 6 dan begitu seterusnya sampai semua kelompok mendapatkan semua kertaas

10. Guru melakukan klarifikasi dengan membaca pernyataan yang ada. Setiap kelompok ditanya jawaban mereka dan dibandingkan dengan jawaban kelompok yang lain

11. Lakukan sampai selesai atau sesuai dengan waktu dan kondisi yang memungkinkan.

\section{Kerangka Konseptual}

Kerangka

konseptual

ini

menggambarkan hubungan antara variabel tindakan dan variabel harapan. Variabel tindakan yaitu mengoptimalkan model pembelajaran "Benar Salah Berantai", sedangkan variabel harapan adalah meningkatkan motivasi dan hasil belajar.

\section{Hipotesis Tindakan}

"Jika penerapan model pembelajaran "Benar Salah Berantai" dilaksanakan secara optimal maka motivasi dan hasil belajar peserta didik kelas IV semester dua tahun pelajaran 2018/2019 dapat ditingkatkan".

\section{METODE PENELITIAN}

\section{Setting Penelitian}

Penelitian tindakan kelas (PTK) ini akan dilaksanakan di kelas IV SD Negeri 30 Mataram semester dua tahun pelajaran 2018/2019, dengan jumlah peserta didik sebanyak 39 Orang.

\section{Faktor yang Diteliti}

- Faktor Guru: yaitu dengan mengganti cara guru membuat Rencana Pelaksanaan Pembelajaran (RPP) dan pelaksanaannya dalam pembelajaran di kelas senyatanya dengan menerapkan model pembelajaran "Benar Salah Berantai" dalam upaya meningkatkan motivasi dan hasil belajar peserta didik Kelas IV SD Negeri 30 Mataram.

- Faktor Peserta Didik: yaitu peningkatan motivasi dan hasil belajar yang terlihat pada perilaku peserta didik selama diskusi kelompok, yang berdampak pada peningkatan motivasi dan hasil belajar peserta didik Kelas IV Semester dua Tahun Pelajaran 2018/2019 di SD Negeri 30 Mataram.

\section{Rencana Tindakan}

kegiatan nyata di kelas IV yaitu melaksanakan proses pembelajaran dengan menerapkan model pembelajaran "Benar Salah Berantai" dalam upaya meningkatkan motivasi dan hasil belajar peserta didik kelas IV SD Negeri 30 Mataram semester dua Tahun Pelajaran 2018/2019. Tindakan nyata yang dilakukan oleh guru selaku peneliti adalah dengan menggunakan siklus. Gambaran siklus dalam penelitian ini adalah sebagai berikut:

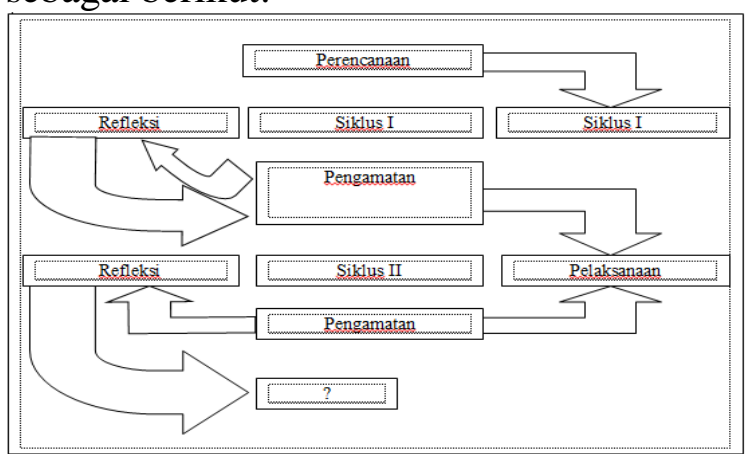

Setiap siklus selama penelitian ini berisi 4 (empat) tahapan yaitu: 1) Perencanaan (Planning), 2) Pelaksanaan (Action), 3) Observasi (Observation), dan 4) Refleksi (Reflection).

\section{Siklus Tindakan \\ SIKLUS I}

\section{1) Tahap Perencanaan (Planning)}

1. Menyusun Rencana Pelaksanaan Pembelajaran (RPP) dengan skenario sesuai dengan aturan main model pembelajaran "Benar Salah Berantai".

2. Menyiapkan sumber, bahan, dan semua alat yang digunakan dalam penelitian. 
3. Menyusun/membuat lembar observasi guru dan lembar observasi peserta didik.

4. Menyusun alat evaluasi.

\section{2) Tahap Pelaksanaan (Action)}

Pada tahapan ini guru selaku peneliti melaksanakan proses pembelajaran dengan penerapan model pembelajaran "Benar Salah Berantai" dengan skenario sebagai berikut :

1. Guru membagi peserta didik menjadi 7 (tujuh) kelompok kecil, masing-masing kelompok beranggotakan 4-5 orang peserta didik.

2. Melakukan proses pembelajaran model pembelajaran "Benar Salah Berantai" sebagai berikut:

\section{Pertemuan I}

1. 1 Setiap kelompok diberi kertas yang sudah berisi pernyataanpernyataan. Dengan ini akan didapatkan kelompok 1 memegang kertas A, kelompok 2 memegang kertas B, kelompok 3 memegang kertass $\mathrm{C}$, dan seterusnya.

1. 2 Tugas setiap kelompok adalah menuliskan pernyataan-pernyataan yang mereka miliki kemudian menentukan apakah pernyataanpernyataan tersebut benar atau salah. Catatan: kertas tidak boleh ditulisi atau diberi tanda apa saja.

1. 3 Setelah semua kelompok selesai melakukan tugas kertas diputar untuk diberikan kepada kelompok disampingnya. Dengan ini kelompok 2 akan mendapatkan kertas baru, kertas A kelompok 3 menerima kertas B kelompok 4 menerima kertas $\mathrm{C}$, dan seterusnya. Sementara kelompok satu akan menerima kertas dari kelompok terakhir

\section{Pertemuan II}

1. Guru melakukan klarifikasi dengan membaca pernyataan yang ada. Setiap kelompok ditanya jawaban mereka dan dibandingkan dengan jawaban kelompok yang lain

2. Lakukan sampai selesai atau sesuai dengan waktu dan kondisi yang memungkinkan.

3. Tes tertulis

\section{3) Tahap Observasi (Observation)}

1. Observasi guru : Dilakukan oleh pengawas mata pelajaran selaku observer sekaligus sebagai pembimbing guru dalam melaksanakan Penelitian Tindakan Kelas (PTK).

2. Observasi Peserta Didik : Dilaksanakan oleh guru kelas sekaligus sebagai peneliti dalam Penelitian Tindakan Kelas (PTK) pada kegiatan diskusi kelompok.

\section{4). Tahap Refleksi (Reflection)}

1. Renungan hasil perolehan data

2. Pengolahan dan analisa data hasil penelitian

3. Mencocokkan hasil analisa data dengan indikator keberhasilan

4. Rencana perbaikan dan tindak lanjut

\section{SIKLUS II}

Pada siklus ini semua kegiatan dan tahapan selama penelitian adalah sama, sifatnya mengulang dan memperbaiki terhadap tindakan yang masih memerlukan penyempurnaan dan pembenaran sebagaimana mestinya.

\section{Data dan Cara Pengambilannya.}

Dalam penelitian ini yang akan dibahas adalah sumber data dan jenis data penelitian, serta cara pengambilan data.

\section{Sumber Data}

Yang menjadi sumber data dalam penelitian tindakan kelas (PTK) ini adalah semua peserta didik kelas IV semester dua tahun pelajaran 2018/2019 di SD Negeri 30 Mataram dan peneliti.

\section{Jenis Data}

- Jenis data yang berasal dari guru selaku peneliti

1). Data tentang Rencana Pelaksanaan Pembelajaran (RPP)

2). Data Pelaksanaan Pembelajaran

- Jenis data yang berasal dari peserta didik :

1). Data kemajuan motivasi belajar

2). Data hasil diskusi kelompok

3). Data hasil belajar

\section{Cara Pengambilan data}

- Data kegiatan pembelajaran diambil dari RPP yang dibuat oleh guru dan 
lembar observasi pelaksanaan model pembelajaran "Benar Salah Berantai"

- Data kemajuan motivasi belajar; diambil dari lembar observasi selama diskusi kelompok.

- Data kemajuan hasil belajar; diambil dari laporan individu hasil diskusi kelompok dan hasil tes tertulis yang dilaksanakan pada akhir proses pembelajaran

\section{Indikator Keberhasilan dan Teknik analisa} data

\section{Teknik analisa data}

Untuk menganalisis data akan dilakukan melalui analisis deskriptif kuantitatif melalui pendataan, analisis dan pembahasan terhadap data yang diperoleh dengan mencocokkan tingkat keoptimalan terhadap capaian indikator keberhasilan yang ada.

\section{Indikator Keberhasilan}

- guru telah dinyatakan berhasil melaksanakan proses pembelajaran "Benar Salah Berantai", bila telah mencapai skor rata-rata $\geq 4,00$ (kategori baik)

- Motivasi belajar peserta didik kelas IV dinyatakan telah meningkat jika $85 \%$ dari jumlah peserta didik telah memperoleh skor rata-rata $\geq 4,0$ dan hasil belajar dinyatakan telah meningkat jika $85 \%$ dari jumlah peserta didik memperoleh nilai rata-rata $\geq 75,00$ (sesuai KKM).

\section{HASIL DAN PEMBAHASAN}

\section{PENELITIAN}

\section{Laporan Hasil}

\section{DESKRIPSI SIKLUS I}

\section{Tahap Perencanaan}

Pada tahapan ini yang telah dilakukan oleh guru selaku peneliti adalah; 1) menyusun RPP dengan skenario pembelajaran "Benar salah Berantai", 2) telah berhasil menyiapkan alat, sumber, bahan yang diperlukan dalam penelitian, 3) berhasil menyusun instrument observasi guru dan instrument observasi peserta didik, dan 4) menyusun alat evaluasi.

\section{Tahap Pelaksanaan}

1. Guru menyampaikan materi pelajaran dengan model pembelajaran "Benar Salah Berantai" dengan kegiatan mengamati dan menanya
2. Peserta didik dibagi menjadi 7 kelompok kecil yang anggotanya $4-5$ orang peserta didik secara heterogen

3. Peserta didik berdiskusi dengan strategi discovery learning dengan kegiatan pokoknya memecahkan persoalan/soalsoal yang menjadi tanggung jawabnya.

4. Selama peserta didik berdiskusi, guru berkeliling membimbing kelompok sekaligus melakukan observasi/pengamatan terhadap aspekaspek yang telah direncanakan.

5. Masing-masing kelompok secara bergiliran mempresentasikan di depan kelas yang diikuti oleh semua anggota kelompok.

6. Guru mengamati/mengobservasi ketrampilan peserta didik selama persentasi sesuai dengan aspek pengamatan ketrampilan yang telah di rencanakan.

\section{Tes tertulis}

\section{Tahap Observasi}

Observasi guru memperoleh skor rata-rata pertemuan I $(3,50)$ dan pertemuan II $(3,93)$, observasi peserta didik memperoleh skor ratarata pertemuan I $(3,26)$ dan pertemuan II $(3,57)$, dampak dari hasil peningkatan motivasi dan hasil belajar adalah perolehan hasil belajar juga meningkat, nilai hasil tugas dan tes tertulis memperoleh nilai rata-rata masing-masing sebesar $(64,46)$ dan $(66,67)$.

\section{Tahap Refleksi}

1. Renungan data hasil perolehan data pada siklus I

2. Pengolahan data hasil observasi guru, Peserta didik dan tes tertulis.

3. Mencocokkan hasil yang ada dengan Indikator keberhasilan.

4. Merencanakan perbaikan terhadap jenis tindakan yang menyebabkan belum tuntas Indikator keberhasilan. Oleh karena Indikator keberhasilan belum terbukti maka penelitian dilanjutkan ke siklus II.

\section{DESKRIPSI SIKLUS II}

\section{Tahap Perencanaan}

Pada tahapan ini jenis kegiatan yang dilakukan masih mengacu pada kegiatan siklus I, bedanya hanya terjadi perbaikan seperlunya yaitu: 1) penyusunan RPP dengan mengacu pada model pembelajaran "Benar 
Salah Berantai" dan penyempurnaan pada bagian skenario pembelajaran, 2) menyiapkan alat, sumber, bahan yang diperlukan dalam proses tindakan dikelas senyatanyan, 3) menyiapkan lembar observasi guru dan lembar observasi Peserta didik sebagaimana pada siklus I, 4) menyiapkan alat evaluasi sebagaimana yang telah dibuat pada siklus I.

\section{Tahap Pelaksanaan}

Secara umum tahapan pelaksanaan proses pembelajaran pada siklus II ini masih mengacu pada pelaksanaan proses pembelajaran sebelumnya. Pemecahan yang dilakukan pada proses pembelajaran ini adalah: 1) pelaksanaan proses diskusi kelompok kecil lebih dioptimalkan, 2) pelaksanaan pembimbingan kelompok sekaligus observasi Peserta didik lebih di efektifkan. Utamanya pengamatan Peserta didik yang termotivasi, yang kurang motivasi, Peserta didik yang tidak termotivasi, dengan harapan proses analisa data lebih signifikan, 3)laporan hasil kerja kelompok yang dibuat secara individu lebih difokuskan, dan 4) pelaksanaan tes tertulis yang merupakan dari peningkatan motivasi dan hasil belajar Peserta didik lebih diperketat.

Tahap Observasi

Observasi guru memperoleh skor ratarata pertemuan I $(4,50)$ dan pertemuan II $(4,71)$, observasi peserta didik memperoleh skor rata-rata pertemuan I $(4,16)$ dan pertemuan II $(4,44)$, dampak dari hasil peningkatan motivasi dan hasil belajar adalah perolehan hasil belajar juga meningkat, nilai hasil tugas dan tes tertulis memperoleh nilai rata-rata masing-masing sebesar $(90,97)$ dan $(85,90)$.

\section{Tahap Refleksi}

1. Renungan atas perolehan data hasil observasi guru, observasi Peserta didik, dan hasil tes tertulis sebagai dampak dari peningkatan motivasi dan hasil belajar Peserta didik di kelas senyatanya.

2. Pengolahan data hasil observasi guru, observasi Peserta didik dan tes tertulis

3. Mencocokkan perolehan data hasil tindakan dengan Indikator keberhasilan yang telah ditetapkan.

Guru memberikan hadiah/reward kepada semua Peserta didik Kelas IV atas keberhasilannya dalam upaya meningkatkan motivasi dan hasil belajar yang berdampak terhadap perolehan hasil belajar sesuai dengan KKM yang telah ditetapkan.

\section{Pembahasan \\ SIKLUS I}

\section{Tahap Perencanaan}

Peneliti telah menyusun RPP dengan skenario penerapan model pembelajaran "Benar Salah Berantai", menyiapkan alat, sumber, bahan yang diperlukan dalam proses pembelajaran, menyusun instrument observasi guru maupun instrument observasi peserta didik mengalami sedikit kendala. Tetapi setelah berkonsultasi kepada pembimbing, kendala yang dihadapi dapat terselesaikan dengan baik.

\section{Tahap Pelaksanaan}

a. Mengamati

- Guru menugaskan kepada peserta didik secara berkelompok untuk menggali informasi dari buku paket tentang materi pelajaran yang disajikan.

- Guru menjelaskan materi pelajaran dan memberikan contoh konkrit yang bisa dimengerti oleh peserta didik

b. Menanya

- Guru memberikan trik-trik kepada peserta didik tentang tata cara bertanya yang baik dan benar sesuai dengan materi pelajaran yang sedang disajikan.

- Peserta didik secara teratur bertanya tentang hal-hal yang belum dimengerti sesuai materi yang sedang dipelajari.

c. Mencoba (mengumpulkan data/informasi)

- Secara berkelompok peserta didik mendiskusikan masalah yang menjadi tanggung jawabnya.

- Melakukan eksperimen dalam kelompok terhaadap permasalahan yang sedang di diskusikan

- Mengumpulkan data yang berasal dari semua anggota kelompok

d. Mengasosiasikan/mengolah informasi

- Semua anggota kelompok menjawab dan menelaah semua jawaban yang telah di diskusikan bersama 
- Hasil jawaban di analisis bersama untuk bisa di paparkan di depan kelas pada saat menyampaikan informasi

- Kelompok membuat kesepakatan akhir dari hasil diskusi kelompok

e. Mengkomunikasikan

1. Guru kembali menyampaikan uraian materi pelajaran terkait dengan hasil kegiatan mengamati, menanya, mencoba, dan mengolah informasi.

2. Guru mempersilahkan kepada semua anggota kelompok untuk menginformaasikan hasil kerja kelompoknya.

3. Semua peserta didik secara berkelompok menanggapi setiap paparan dari kelompok lain

4. Peserta didik dengan bimbingan guru membuat kesimpulan bersama dari seluruh permasalahan/soal yang menjadi tanggung jawabnya.

5. Tes tertulis.

\section{Tahap Observasi}

Observasi guru memperoleh skor ratarata pertemuan I $(3,50)$ dan pertemuan II $(3,93)$, Hasil observasi peserta didik dalam upaya peningkatan motivasi dan hasil belajar peserta didik kelas IV semester dua tahun pelajaran 2018/2019 di SD Negeri 30 Mataram diperoleh skor rata-rata pertemuan I $(3,26)$ dan tahap II $(3,57)$. Dari hasil tes tertulis yang materinya hanya sekitar yang diajarkan pada saat itu juga, diperoleh nilai rata-rata $(66,67)$ kategori cukup, sedangkan tugas individual rata-rata $(64,46)$

\section{Tahap Refleksi}

Hasil analisa data peningkatan motivasi belajar pada siklus I ini $(3,26)$ dan presentasi kelompok $(3,57)$, sedangkan yang diminta dalam Indikator keberhasilan $(\geq 4,0)$, ini artinya belum berhasil. Karena Indikator keberhasilan belum tercapai, penelitian tindakan kelas (PTK) dilanjutkan ke siklus II dengan harapan optimalisasi penerapan strategi pembelajaran dengan model pembelajaran "Benar Salah Berantai" dapat meningkatkan motivasi belajar peserta didik kelas IV semester dua tahun pelajaran 2018/2019 di SD Negeri 30 Mataram.

\section{SIKLUS II}

\section{Tahap Perencanaan}

Peneliti menyusun Rencana Pelaksanaan Pembelajaran (RPP) dengan memperhatikan kesalahan-kesalahan pada siklus I. peneliti lebih memfokuskan tentang Rencana strategi jitu sehingga proses pembelajaran dengan model pembelajaran "Benar Salah Berantai" dapat terelaisasi dengan baik, karenanya dalam penyusunan skenario benar-benar dirinci dari tiap aspek pada proses pembelajaran dengan model pembelajaran "Benar Salah Berantai".

Sebelum proses pembelajaran dilaksanakan, peneliti menyiapkan semua alat, bahan, dan segala sesuatunya sehingga dalam pelaksanaan proses pembelajaran berjalan sesuai dengan skenario yang telah direncanakan. Agar proses pembelajaran dapat teratasi maka peneliti juga menyiapkan lembar observasi guru dan lembar observasi peserta didik sebagai tolak ukur ketercapaian peningkatan motivasi dan hasil belajar peserta didik kelas IV SD Negeri 30 Mataram.

\section{Tahap Pelaksanaan}

Pada tahap pelaksanaan di siklus II ini pada dasarnya masih mengacu pada pelaksanaan siklus I, yaitu penerapan model pembelajaran "Benar Salah Berantai". Bedanya pada siklus ini lebih dioptimalkan.

\section{Tahap Observasi}

Pada siklus II ini hasil observasi guru memperoleh skor rata-rata pertemuan I $(4,50)$ dan pertemuan II $(4,71)$. Upaya meningkatkan motivasi belajar peserta didik kelas IV semester dua tahun pelajaran 2018/2019 di SD Negeri 30 Mataram pada tahap I diperoleh skor rata-rata pertemuan I $(4,16)$ dan pertemuan II $(4,44)$. Dampak nyata dari meningkatnya motivasi belajar adalah hasil belajar juga meningkat, dari data hasil perolehan nilai rata-rata tugas individual $(90,97)$ dan tes tertulis adalah $(85,90)$ sementara pada siklus sebelumnya hanya $(64,46)$ dan $(66,67)$ berarti mengalami peningkatan yang sangat signifikan.

\section{Tahap Refleksi}

Hasil analisa data peningkatan motivasi dan hasil belajar peserta didik pada siklus II adalah $(4,16)$ dan $(4,44)$ serta $(90,97)$ dan $(85,90)$ sedangkan Indikator keberhasilan $(\geq$ $4,0)$ dan $\geq 75,00$. Ini artinya pada siklus II 
hasilnya telah melampaui Indikator keberhasilan yang telah di tetapkan.

Karena Indikator keberhasilan telah terbukti, maka tidak perlu ada upaya perbaikan dan penyempurnaan. Model pembelajaran "Benar Salah Berantai" telah mampu meningkatkan motivasi dan hasil belajar peserta didik yang ditandai dengan tercapainya Indikator keberhasilan dan terjadinya peningkatan hasil belajar peserta didik. "Penelitian Tindakan Kelas (PTK) dihentikan pada siklus II dengan hasil memuaskan."

\section{Simpulan}

Data komulatif dari hasil penelitian tindakan kelas (PTK) dari siklus I ke Siklus II adalah sebagai berikut:

\begin{tabular}{|c|c|c|c|c|c|c|c|}
\hline \multirow{2}{*}{ No } & \multirow{2}{*}{ Jenis Kegiatan } & \multirow{2}{*}{$\begin{array}{c}\text { Indikator } \\
\text { keberhasilan }\end{array}$} & \multicolumn{2}{|c|}{ Silklus I } & \multicolumn{2}{|c|}{ Silklus II } & \multirow{2}{*}{ Keterangan } \\
\hline & & & I & II & I & II & \\
\hline 1. & Observasi Guru & $\geq 4,00$ & 3,50 & 3,93 & 4,50 & 4,71 & Meningkat \\
\hline 2. & Observasi Peserta didik & $\geq 4,00$ & 3,26 & 3,57 & 4,16 & 4,44 & Meningkat \\
\hline 3. & Tugas individual & $\geq 75,00$ & \multicolumn{2}{|c|}{64,46} & \multicolumn{2}{|c|}{90,97} & Meningkat \\
\hline 4. & Tes tertulis & $>75,00$ & \multicolumn{2}{|c|}{66,67} & \multicolumn{2}{|c|}{85,90} & Meningkat \\
\hline
\end{tabular}

Penerapan model pembelajaran

"Benar Salah Berantai" sangat efektif upaya untuk meningkatkan motivasi dan hasil belajar peserta didik kelas IV semester dua tahun pelajaran 2018/2019 di SD Negeri 30 Mataram. Fakta telah menunjukkan perolehan rata-rata skor motivasi belajar peserta didik pada siklus I ke siklus II sudah melampaui Indikator keberhasilan yang ditetapkan. Penelitian dinyatakan "berhasil" dan dihentikan pada siklus II.

\section{SARAN}

Disarankan kepada guru sejawat untuk melaksanakan Penelitian Tindakan Kelas (PTK) dalam upaya untuk meningkatkan motivasi dan hasil belajar peserta didik sesuai dengan mata pelajaran masing-masing.

Disarankan kepada para semua peserta didik kelas IV SD Negeri 30 Mataram untuk membiasakan belajar dengan pendekatan yang kontekstual utamanya strategi yang mampu membangkitkan motivasi belajar peserta didik yang dampaknya hasil belajar dapat ditingkatkan seperti yang diharapkan.

\section{DAFTAR PUSTAKA}

Arikunto, s. 2009, Penelitian Tindakan Kelas, Jakarta : Bumi Aksara.
Harun Rasyid dan Mansur, 2008, Penilaian Hasil Belajar, Bandung : CV Wacana Prima.

Lukmanul A, 2008, Perencanaan Pembelajaran, Bandung : CV Wacana Prima.

Mukhtar, 2003, Prosedur Penilaian, Jakarta : Rineka Cipta.

Nurhadi, 2003, Yasin ,B dan Sendule.A, 2003, Kontekstual dan Penerapannya dalam KBK, Malang : Unitipetas Negeri Malang.

Robert E Slavin, 2010, Cooperative Learning Teori, riset dan Praktik, Bandung : Nusa Media.

Sardiman, 2007, Indikator Dan Motivasi Belajar Mengajar, Jakarta : Raja Grafindo Perkasa.

Supriono, 2009, Cooperative Learning Teori dan Aplikasi PAIKEM, Yogyakarta : Pustaka Pelajar.

Permen 81A Tahun 2013 Tentang Implementasi Kurikulum 2013

Permen 103 Tahun 2014 Tentang Standar Proses 